\title{
PENGKODEAN DALAM PEMBELAJARAN PENULISAN SASTRA
}

\author{
Tsalits Abdul Aziz Al farisi
}

\author{
Fakultas Kegurian Ilmu Pendidikan Universitas Islam Darul Ulum Lamongan \\ Drumbig_tsalis@yahoo.co.id
}

\begin{abstract}
The purpose of this research is to describe it 1) how is the coding system for creating poetry. 2) how can student understand objects in the ward then applied to the text of diction. 3) how can students create certain diction in relation to what one imagines. The methods in this research are using quantitatif methods with model design patterns using media as a basis for finding a purpose the study of literature at SMA Kanjeng Sepuh school X class. The result of this study is the observation table of assessments stuents interest in literature especially the poem. On other side of the observation of teacher and student activities carrying out the study of poetry is also a focus quantitatif data results. The conclusion of this study is to find a point of literary learning accuracy through quantitatif measures in coding systems. It needs to be used to find the concrete steps the literary writing learning pattern that currently is of little interest to students.
\end{abstract}

Keyword: diction, code, poem, learning.

\begin{abstract}
Abstrak: Tujuan penelitian ini adalah mendeskripsikan tentang 1) bagaimana sistem pengkodean dalam menciptakan puisi. 2) bagaimana siswa dapat menyerap objek yang ada di lingkungan kemudian diaplikasikan ke dalam teks berupa diksi. 3) bagaimana siswa dapat menciptakan diksi-diksi tertentu terkait dengan apa yang diimajinasikan. Metode dalam penelitian ini menggunakan metode penelitian kuantitatif dengan pola ranncangan model penggunaan media sebagai titik dasar untuk menemukan tujuan pembelajaran sastra di sekolah SMA Kanjeng Sepuh Sidayu kelas X. Hasil dari penelitian ini adalah tabel observasi penilaian minat siswa terhadap sastra khususnya puisi. Di sisi lain observasi aktivitas guru dan siswa dalam melaksan akan pembelajaran puisi juga menjadi fokus hasil data secara kuantitatif. kesimpulan penelitian ini adalah untuk menemukan titik akurasi pembelajaran sastra melalui sistem pengkodean dengan langkah secara kuantitatif. Hal tersebut perlu digunakan untuk menemukan langkah kongkret pola pembelajaran penulisan sastra yang saat ini kurang diminati oleh siswa SMA khususnya kelas X.
\end{abstract}

Kata Kunci: diksi, kode, puisi, pembelajaran.

\section{PENDALUHULUAN}

Dalam pebelajaran bahasa Indonesia dan sastra Indonesia ada empat aspek yang harus dikuasai oleh siswa yaitu mendengarkan, berbicara, membaca dan menulis. Keempat aspek tersebut saling mendukung keberadaannya (Tarigan, 2008:1). Oleh sebab itu, dalam setiap kegiatan pembelajaran guru diharapkan mampu mengaitkan situasi kehidupan nyata dengan materi yang sedang dipelajari di lingkungan kelas, sebagai bagian dari kegiatan pembelajaran, hal ini bertujuan agar pembelajaran yang dilakukan guru menjadi lebih efisien. Menulis puisi merupakan kegiatan produktif yang lahir dari ekspresi pribadi. Menulis puisi membutuhkan bahan tertentu. Bahan tersebut ialah realitas kehidupan, pengalaman sehari-hari baik lahir maupun batin.

Masyarakat sering menganggap
bahwa ketrampilan menulis puisi
merupakan bakat sehingga orang yang
merasa tidak mempunyai bakat tidak dapat
menulis puisi. Sebaliknya, tanpa bakat pun
bila seseorang dapat raji belajar dan giat
berlatih, dia akan terampil menulis puisi
(Wiyanto, 2005:48). Kepandaian menulis


puisi bergantungnpada pengalaman menulis puisi seseorang. Penanaman kebiasaan menulis puisi harus dilakukan seak dini agar terbawa sampai dewasa. Siswa harus mendapat dorongan untuk belajar serta mendapat kesempatan untuk mengekspresikan keinginan dan isi hatinya dalam berbagai bentuk seperti puisi. Pelatihan menulis puisi perlu dilakukan untuk mempertajam pengamatan dan meningkatkan kemampuan berbahasa.

Sejak Sekolah Dasar kelas III (kurikulum 2004), materi puisi sudah diperkenalkan dan diajarkan, yakni tentang pemahaman dan penulisannya dalam menggunakan kata-kata atau isi dari puisi artinya siswa masih menggunakan katakata sehari-hari dalam penulisan puisinya, sehingga secara logika siswa lebih mudah memahami dan menulis puisi. Akan tetapi, kenyataannya persentase kegemaran siswa terhadap puisi hanya sebagian kecil, karena materi tentang puisi kurang mendapat perhatian dan dianggap sulit. Di sisi lain remaja remaja cenderung menyukail puisi dibandingkan dengan tingkat usia anakanak dan dewasa. Semua pengalaman, dan luapan perasaannya dituangkan dalam bentuk puisi.

Penelitian ini dilakukan di SMA Kanjeng Sepuh Sidayu, khususnya kelas X. karena, menurut peneliti, sejak pengamatan pada tanggal 20 Desember 2012, peneliti menemukan adanya respon yang kurang positif terhadap minat siswa dalam belajar menulis dan mengapresiasi puisi. Fenomena tersebut muncul dari kurang adanya sosialisasi pembelajaran puisi yang dapat merangsang emosi siswa untuk bisa berkembang dalam mengapresiasi puisi. Peneliti juga sempat berbincang perihal kondisi siswa selama belajar bahasa Indonesia, terutama mengenai puisi. Hasil dari dialog tersebut menyebutkan bahwa menurut para siswa,puisi merupakan materi pelajaran yang rumit untuk dipahami, terutama mengenai mengapresiasi puisi. Sang guru pun tidak memiliki bekal apaapa mengatasi permasalahan tersebut. Yang dilakukan guru adalah tetap mengajar sesuai dengan kurikulum dan membiarkan siswa untuk tetap menyimak dan mempelajari materi yang guru sajikan.

Melihat fenomena di atas, peneliti mencoba untuk menawarkan solusi pembelajaran dengan model pengkodean diksi. Pengkodean tersebut berfungsi sebagai solusi bagi siswa yang kesulitan dalam mengapresiasi puisi. Bentuk pengkodean tersebut melalui media gambar atau tulisan yang diberi kode diksi mana yang menurut siswa kurang dimengerti. Lalu diksi tersebut dikumpulkan dengan cara digunting atau ditandai dengan stabile atau perangkat lainnya yang sekirannya bisa menandai bahwa itu adalah kode penandaan diksi. Kemudian, jika sudah terkumpul, maka peneliti, siswa, dan guru berdiskusi mengenai diksi tersebut. Hasil dari diskusi tersebut dikumpulkan, lalu diinterpretasikan bersama-sama dengan murid.

\section{Kajian Pustaka}

\section{- Hakikat menulis}

Menulis merupakan suatu kemampuan berbahasa. Dalam kamus besar bahasa Indonesia (Depdikbud, 2002:12-19) menulis diartikan, (1) membuat huruf (angka dsb) dengan pena, (2) melahirkan pikiran atau perasaan (seperti mengarang, membuat surat) dengan tulisan. Menuru tarigan (2008: 21) menulis merupakan kegiatan menurunkan atau melukiskan lambing-lambang grafik yang menggambarkan suatu bahasa yang dipahami oleh seseorang sehingga orang lain dapat membaca lambing-lambang grafik tersebut kalau mereka memahami bahasa dan gambaran grafik tersebut.

Dari kesimpulan diatas, dapat disimpulkan bahwa menulis merupakan kegiatan menghasilkan tulisan yang berfungsi sebagai suatu alat komunikasi dalam bentuk tulis dan bisa digunakan sebagai sarana komunikasi secara tidak langsung. Ketrampilan menulis tidak akan 
dating secara otomatis, melainkan harus melalui latihan dan praktik secara langsung dan juga adanya suatu rangsangan lingkungan sekitar agar kegiatan menulis tesebut lancar.

\section{Menulis Puisi}

Menurut Tjahjono (2000: 36) resep menjadi seorang penyair adalah yang utama menulis. Serta berdiskusi atau mendiskusikan puisi dengan orang lain yang memiliki korelasi pengetahuan mengenai sastra terutama puisi atau teman yang memiliki pengalaman lebih.

Dalam menulis puisi ada peralatanperalatan yang bersifat umum. Hal tersebut sebagai perjalanan kreativitas dalam penyusunan puisi. Menurut Tjahjono (2000: 37-41) bekal tersebut meliputi :

1) Bahan puisi ialah realitas kehidupan, pengalaman sehari-hari

2) Bahasa puisi adalah bahasa yang khas. Berbeda dengan bahasa karya atau tulisan yang lain. Pilihan katakatanya harus sungguh padat dan cermat disamping menyuarakan perasaan penyairnya.

3) Bentuk ekspresi, bentuk menyangkut visualisasi puisi, yang dibentuk oleh larik dan bait. Pada umumnya satu bait mengandung satu pokok pikiran. Satu bait dapat terdiri dari atas satu larik atau lebih.

4) Pengembangan bahan puisi sebenarnya bukan sekadar ungkapan perasaan penyair, tetapi juga pemikirannya.

5) Gagasan pribadi, dalam puisi gaya itu terlihat pada pilihan kata, penyusunan frase atau kalimat, pengolahan majas, penggarapan unsur intrinsic puisi, baris, dan bait, tipografi, enjambemen, dan irama serta pemilihan dan pengungkapan pokok persoalan.

\section{Pengertian Puisi}

$\begin{array}{rcr}\text { Pradopo } & (2005: & 7) \text { menyatakan } \\ \text { bahwa puisi itu mengekspresikan }\end{array}$ pemikiran yang membangkitkan perasaan yang merangsang imajinasi panca indera dalam susunan berirama. Sedangkan Tarigan (dalam Djojosuroto, 2006:10) mengatakan bahwa kata puisi berasal dari bahasa Yunani "poesis" yang berarti penciptaan. Dalam bahasa Inggris puisi disebut poetry yang berarti puisi, poet berarti penyair, poem berarti syair, sajak. Arti semacam ini lama kelamaan dipersempit ruang lingkupnya menjadi "hasil seni sastra yang kata-katanya disusun menurut syarat-syarat tertentu dengan menggunakan irama, sajak, dan kata-kata kiasan". Dapat dikatakan bahwa puisi adalah pengucapan dengan perasaan, sedangkan prosa pengucapan dengan pikiran.

Puisi pada teknik penulisannya pun punya ciri tertenut, misalnya margin, barisnya yang memiliki mekanisme kepenulisan sendiri. Dengan demikian seberapa lebar pun halaman tempat puisi itu ditulis, puisi itu selalu tertulis dengan cara yang sama. Dalam hal ini, penyair menentukan panajng bari atau ukuran (djojosuorto, 2006:9)

\section{Struktur Puisi} besar yaitu:

Struktur ini meliputi dua bagian

\section{Struktur Fisik Puisi}

a. Diksi

Menurut Boulton (dalam Djojosutoro, 2006:16) diksi merupakan esensi seni penulisan puisi. Ada pula yang menyebut diksi sebagai dasar bangunan puisi. Kata-kata yang dipilih penyair menentukan pemilihan kata. Jika dihubungkan dengan lambing, maka sebuah kata mungkin melambangkan sesuatu, efek yang dihasilkan oleh kata tertentu akan mempunyai makna tertentu pula.

b. Gaya bahasa 
Tujuan menciptakan gaya bahasa dalam puisi, antara lain (1) agar menghasilkan kesenangan yang bersifat imajinatif, (2) agar menghasilkan makna tambahan, (3) agar dapat menambah intensitas dan menambah konkrit sikap dan perasaan penyair, dan (4) agar makna yang diungkapkan lebih padat (Perine dalam Djojosuroto, 2006:17).

Gaya bahasa dapat dibagi menjadi dua pokok, yaitu (1) pengiasan dan (2) pelambangan. Ambrams dan Rachmat Djoko Pradopo membagi majas ke dalam lima bagian yaitu: metafora, simile, personifikasi, metonimi dan sinekdok. Sedangkan perine membagi lambing ke dalam empat bagian yaitu lambing benda, bunyi, warna dan suasana (Pradopo dan Perini dalam Djojosuroto, 2006: 17)

c. Bunyi

Peranan bunyi mendapat
oerhatian penting dalam menentukan makna yang dihasilkan puisi, jika puisi dibaca. Pembahasan bunyi di dalam puisi menyangkut masalah rima, ritma dan metrum. Rima berartu persamaan atau pengulangan bunyi, sedangkan rima berarti pertentangan bunyi yang berulang secara teratur yang membentuk gelombang antar baris puisi. Emtrum adalah variasi tekanan atau suku kata (Boulton, Wellek dan Warren dalam Djojosuroto, 2006: 22)

\section{- Struktur Batin Puisi}

a. Tema

Gagasan pokok yang
dikemukakan penyair r lewat
puisisnya. Tema puisi biasanya
mengungkapkan persoalan manusia
yang bersifat hakiki, seperti: cinta
kasih, ketakutan, kebahagiaan,
kritik sosial, (Djojosuroto, 2006: 24$)$
Tema dapat dijabarkan
menjadi subtema atau bisa

dikatakan pokok pikiran. Puisi seringkali tidak mengungkapkan tema yang umum, tetapi tema yang khusus yang dapat diklasifikasikan ke dalam subtema atau pokok pikiran (Budidarma dalam Djojosuroto, 2006: 24).

b. Nada

Nada sering dikaitkan dengan suasana. Jika nada berarti sikap penyair terhadap pokok persoalan dan sikap terhadap pembaca, maka, suasana berarti keadaan perasaan yang ditimbulkan oleh pengungkapan nada dan lingkungan yang dapat ditangkap oleh panca indera (Efendi dalam Djojosuroto, 2006: 25).

c. Perasaan

Dalam puisi diungkapkan perasaan penyair. Puisi dapat mengungkapkan perasaan gembira, sedih, terharu, takut, gelisah, rindu, dan lain sebagainya. Perasaan yang diungkapkan penyair bersifat total, artinya tidak setengah-setengah. Jika yang diungkapkan adalah perasaan sedih, maka kesedihan itu bersifat total. Oleh sebab itu, penyair mengerahkan segenap kekuatan bahasa untuk memperkuat ekspresi perasaan yang bersifat total itu (Tarigan dalam Djojosuroto, 2006: 26).

\section{d. Amanat}

Puisi mengandung amanat atau pesan atau himbauan yang disampaikan penyair kepada pembaca. Amanat dibandingkan dengan kesimpulan tentang nilai atau kegunaan puisi itu bagi pembaca.

\section{- Pengertian Media}

Kata media berasal dari bahasa latin dan merupakan bentuk jamak dari kata medium yang secara harfiah berarti 
perantara atau pengantar (Sadiman, 2008:6). Banyak batasan yang diberikan orang tentang media, Asosiasi Teknologi dan Komunikasi Pendidikan di Amerika membatasi media sebagai segala bentuk dan saluran yang digunakan orang untuk menyalurkan pesan/informasi. Gagne (1970) menyatakan bahwa media adalah berbagai jenis komponen dalam lingkungan sisya yang dapat merangsangnya untuk belajar. Sementara itu Briggs (1970) berpendapat bahwa media ialah segala alat fisik yang dapat menyajikan pesan serta merangsang siswa untuk belajar buku, film, bingkai adalah contoh-contohnya (Sadiman, 2008:6)

Media adalah bentuk-bentuk komunikasi baik tercetak maupun audiovisual serta peralatannya (Asosiasi Pendidikan Nasional dalam Sadiman, 2008: 7). Media ada;ah semua bentuk perantara yang dipakai oleh penyebar ide, sehingga ide atau gagasan itu sampai pada penerima. Media merupakan saluran karena pada hakikatnya media telah memperluas atau memperpanjang kemampuan manusia untuk merasakan, mendengar dan melihat dalam batas-batas jarak, ruang dan waktu tertentu. Dengan bantuan media batas-batas itu hampir menjadi tidak ada (McLuhan dalam Rohani, 1997:2)

Media adalah saluran komunikasi atau medium yang digunakan untuk membawa/menyampaikan pesan, dimana medium ini merupakan jalan atau alat dengan mana suatu pesan berjalan antara komunikator dengan komunikasi.

Dengan beberapa definisi tersebut dapat disimpulkan bahwa media adalah segala alat yang digunakan untuk menyampaikan pesan kepada penerima pesan (siswa) sehingga menimbulkan motivaasi dan bermanfaat bagi penerimanya (siswa).

\section{- Peranan Media}

a. Mengatasi perbedaan pengalaman pribadi peserta pendidik misalnya : peserta didik yang bertempat tinggal dipegunungan yang belum pernah lihat lautan dapat digunakan media kaset, film audio visual.

b. Mengatasi batas-batas ruang kelas, misalnya : benda-benda yang ada didalam kelas sulit dibawa ke dalam kelas. Dapat diajarkan melalui film strip, film slide, dan lain sebagainya.

c. Mengatasi kesulitan apabila benda secara tidak langsung tidak dapat diamati karena terlalu kecil, misalnya: sel, atom, bakteri dapat menggunakan media film, atau slide

d. Mengatasi peristiwa-peristiwa alam misalnya: terjadinya letusan gunung berapi, pertumbuhan tumbuhsn atau pembiakkan binatang, dapat digunakan media gambar, film, dan sebagainya.

e. Memberikan kesamaan/kesatuan dalam pengamatan terhadap sesuatu yang pada awal pengamatan peserta didik berbeda-beda

f. Membangkitkan minat belajar yang baru dan membangkitkan motivasi kegiatan belajar peserta didik.

\section{Metode Penelitian}

Metode dalam penelitian ini menggunakan metode penelitian kuantitatif dengan pola ranncangan model penggunaan media sebagai titik dasar untuk menemukan tujuan pembelajaran sastra di sekolah SMA Kanjeng Sepuh Sidayu kelas $\mathrm{X}$.

\section{Instrumen Penelitian}

Instrument atau alat pengambilan data dalam penelitian ini berdasarkan rancangan penelitian meliputi hal-hal berikut:

1) Observasi Kebutuhan Siswa

Observasi dilakukan untuk mengetahui identifikasi kebutuhan siswa, yaitu kemampuan, keterampilan, dan sikap siswa dengan cara menyebarkan angket kepada siswa. 
2) Angket Respon Siswa

Angket respon siswa dilakukan berdasarkan tes uji coba atau pada tahap evaluasi. Respon siswa meliputi sering atau tidaknya, senang atau tidaknya dan setuju atau tidaknya sisiwa menggunakan pengkodean diksi kata dalam pembelajaran menulis puisi.

\section{3) Instrumen Observasi Aktivitas Guru dan Aktivitas Siswa}

Lembar aktivitas guru dan aktivitas siswa merupakan deskripsi aktivitas guru dan siswa dari hasil pengamatan mengenai pelaksanaan proses pembelajaran bahasa dan sastra Indonesia dalam menulis puisi.

\section{Teknik Pengumpulan Data}

Teknik pengumpulan data dalam penelitian ini akan dirinci oleh peneliti sebagai berikut:

\section{1) Observasi}

Observasi dilakukan secara langsung pada saat pembelajaran menulis puisi di kelas $\mathrm{X}$ dengan pokok bahasan menulis puisi dan menganalisis puisi yang sudah disediakan oleh peneliti. Lembar observasi ini bertujuan untuk mendapatkan data tentang situasi kelas pada saat pembelajaran berlangsung, yang meliputi identifikasi kebutuhan siswa dalam pembelajaran menulis puisi, aktivitas siswa dan guru, serta respon siswa terhadap media yang disajikan. Hasil pengambilan observasi dilakukan dengan mengamati semua aktivitas yang terjadi di kelas, dengan mengisi angket yang telah disediakan.

\section{2) Produk}

Untuk mengetahui kemampuan siswa dalam mengapresiasi puisi, peneliti menggunakan produk.
Produk ialah cara yang dapat digunakan oleh peneliti untuk mengumpulkan data yang menunjuk suatu kata yang abstrak dan tidak diwujudkan dalam benda, tetapi hanya dapat dilihatkan penggunaannya melalui sebuah produk hasil belajar yaitu dengan menggunakan tes (Ridwan, 2009: 24). Tes mengapresiasi puisi tersebut berdasarkan ketentuan sebagai berikut:

a. Tes mengapresiasi puisi, guru memberikan model pengkodean diksi (dari kmpulan puisi yang sudah disajikan oleh guru) yang akan digunakan siswa untuk mengapresiasi puisi.

b. Puisi yang diapresiasi siswa merupakan hasil dari pengkodean yang sudah ditentukan sebelumnya.

\begin{tabular}{|c|l|l|l|}
\multicolumn{4}{|c|}{ Aspek yang Dinilai } \\
\begin{tabular}{|c|l} 
N \\
o
\end{tabular} & $\begin{array}{l}\text { Aspek } \\
\text { yang } \\
\text { Dinilai }\end{array}$ & $\begin{array}{l}\text { Bob } \\
\text { ot }\end{array}$ & $\begin{array}{l}\text { Sk } \\
\text { or }\end{array}$ \\
\hline 1 & Diksi & 50 & \\
\hline 2 & $\begin{array}{l}\text { Proses } \\
\text { kepenulis } \\
\text { an puisi }\end{array}$ & 50 & \\
\hline & Jumlah & 100 & \\
\hline
\end{tabular}

Keterangan:

a) Diksi (mengambil diksi pada kumpulan puisi yang sudah disajikan peneliti)

b) Proses kepenulisan (proses siswa dalam menulis puisi yang nanti akan diapresisasi bersama kepada siswa yang lain)

Keterangan Skor:

1. Skor $85-100$ : baik sekali

2. Skor 75-84: baik

3. Skor 66-74: cukup 
4. Skor kurang dari 65: kurang.

\section{Teknik Analisis Data}

Penelitian ini menggunakan analisis deskripitf, yakni analisis dengan penggambaran suatu penelitian baik dalam bentuk angka, tabel, dan sebagainya. Untuk menjelaskan tujuan penelitian, data-data yang dianalisis adalah sebagai berikut:

\section{1) Analisis Hasil Penilaian}

Data hasil penilaian serta analisis hasil pengamatan aktivitas guru dan siswa dianalisis secara deskriptif kualitatif. Selanjutnya dianalisis menggunakan rumus:

Penilaian $=\frac{\text { jumlah skor penilaian }}{\text { jumlah skor tinggi }} \times 100$

2007: 40)

Keterangan : $\mathrm{P}=$ Penilaian

\section{HASIL DAN PEMBAHASAN Observasi Kebutuhan Siswa}

Pada analisis ini, peneliti mulamula akan mengawali dengan observasi terhadap kebutuhan siswa. Observasi ini meliputi beberapa hal saja, mengingat banyak hal yang sedikit menjadi kendala mengenai hal ini. Namun, data berikut cukup untuk memahami observasi peneliti terhadap siswa yang memahami dan mengapresiasi pembelajaran puisi.

\begin{tabular}{|c|c|}
\hline $\begin{array}{l}\text { Observasi } \quad \text { Kebutuhan } \\
\text { Siswa }\end{array}$ & Hasil \\
\hline $\begin{array}{l}\text { A. Minat siswa } \\
\text { terhadap } \\
\text { pembelajaran puisi }\end{array}$ & $\begin{array}{ll}\text { Tidak } & \\
\text { suka } & 25 \\
\text { siswa } & \\
\text { Suka } & 7 \\
\text { siswa } & \end{array}$ \\
\hline $\begin{array}{l}\text { B. Apakah mengalami } \\
\text { kesulitan belajar } \\
\text { puisi }\end{array}$ & $\begin{array}{l}\text { Sulit } 23 \\
\text { Tidak sulit } \\
9\end{array}$ \\
\hline
\end{tabular}

\begin{tabular}{|c|l|l|}
\hline $\begin{array}{l}\text { C. Apakah pernah } \\
\text { menulis puisi }\end{array}$ & $\begin{array}{l}\text { Pernah 20 } \\
\text { Tidak } \\
\text { pernah 12 }\end{array}$ \\
\hline $\begin{array}{l}\text { D. Apakah pernah } \\
\text { membaca puisi, } \\
\text { buku kumpulan } \\
\text { puisi }\end{array}$ & $\begin{array}{l}\text { Pernah 10 } \\
\text { Tidak } \\
\text { pernah 22 }\end{array}$ \\
\hline $\begin{array}{l}\text { E. Apakah ada yang } \\
\text { mengenal beberapa } \\
\text { penulis } \\
\text { Indonesia }\end{array}$ & Tidak \\
kenal 24 \\
Kenal 8
\end{tabular}

Data diatas bisa diperkirakan bahwa beberapa minat siswa terhadap pembelajaran puisi masih kurang minatnya. Dengan alasan yang beragam, salah satunya mereka tidak menyukai perihal kerumitan aknai puisi secara impresif. Sehingga kaan mereka (menurut pengamatan liti) terhadap pemahaman puisi sangat ng. Selain itu, ada pula siswa yang berminat belajar puisi, ini hanya beberapa sisi saja. Alasan mereka menyukai puisi karena keberminatannya terhadap bahasa puisi yang cocok untuk mengespresikan perasaannya.

Sementara, mereka ada yang mengalami kesulitan belajar puisi dengan alasan rata-rata proses pembelajarannya yang membingungkan. Ada beberapa siswa yang pernah ngomong dengan peneliti bahwa model pembelajarannya tidak efektif. Ini dikarenakan guru yang kurang baik dalam mengelola pola pembelajaran puisi. Hanya ada beberapa siswa saja yang tidak mengalami kesulitan. Entah ini semacam alasan kecil saja siswa untuk memberikan respon positif terhadap peneliti. Karena peneliti mengamati beberapa siswa yang mengalami kesulitan sedikit terbantu berkat adanya beberapa dari mereka mengikuti kegiatan ekstrakulikuler diskusi sastra yang diadakan rutin sebagian kelompok kecil siswa.

Menulis puisi merupakan hal yang cukup diminati siswa. Jumlahnya mencapai 20 siswa dari 32 siswa. Banyak alasan mereka yang menyukai menulis puisi, 
disamping untuk menuangkan ekspresi, mereka lebih menuangkannya untuk berpacaran dan untuk keragaman bentuk sosial yang lain. Sementara ketidakminatan untuk menulis puisi, kebanyakan dari mereka karena nggak ada waktu dan tidak mempunyai perbendaharaan kata yang cukup untuk menulisnya.

Pengalaman membaca puisi bagi para siswa SMA Kanjeng Sepuh sangat minim. Hal ini dikarenakan tidak dibudayakannya membaca dan mengapresiasi oleh pihak sekolah. Pihak sekolah baru beberapa saat ini saja mulai memfasilitasi beberapa buku-buku dan memberikan ruang belajar sastra untuk komunitas siswa-siswa yang berminat untuk belajar sastra.

Pengetahuan siswa terhadap sastrawan, penyair nasional sangat minim. Ini disebabkan tidak kepedulian mereka dengan sastra dan kurang andilnya guru untuk memperkenalkan tokoh-tokoh sastra masa dahulu dan sekarang. Namun, hanya beberapa saja yang mengenal tokoh-tokoh sastra nasional. Walaupun hanya menyebut beberapa sastrawan yang terkenal saja, semisal Rendra, Chairil Anwar, Sutardji Calzoum Bachri. Hasil di atas diperoleh hasil rata-rata kebutuhan siswa yang berpotensi menyukai pembelajaran puisi dari kualifikasi diatas berdasarkan urutannya sebagai berikut:
A. $\frac{25}{7} x 100=35,7 \%$
B. $\frac{23}{9} x 100=25,5 \%$
C. $\frac{20}{12} \times 100=16,6 \%$
D. $\frac{10}{22} \times 100=4,54 \%$
E. $\frac{24}{8} \times 100=30,0 \%$

Dari uraian diatas dapat disimpulkan bahwa rata-rata observasi kebutuhan siswa dalam pembelajaran puisi ratarata mencapai $28,5 \%$. Dari sekian susunan yang didapat oleh peneliti, poin A merupakan prosentase yang tinggi. Ini dimungkinkan kurangnya minat belajar puisi pada siswa dikarenakan proses pembelajaran terhadap puisi didalam kelas kurang kreatif.

\section{Angket Respon Siswa}

Pada penelitian ini, peneliti mencoba untuk menjabarkan beberapa hasil tawaran yang peneliti ajukan kepada siswa. Tawaran tersebut berbentuk angket mengenai setuju atau tidaknya pembelajaran puisi dengan model pengkodean diksi.

\begin{tabular}{|r|l|}
\hline Observasi Minat Siswa & $\begin{array}{l}\text { Respon } \\
\text { Siswa }\end{array}$ \\
\hline A. Pengkodean Diksi & $\begin{array}{l}\text { Suka 20 } \\
\text { Tidak suka } \\
12\end{array}$ \\
\hline B. $\begin{array}{l}\text { Mengapresiasi puisi } \\
\text { dengan } \\
\text { menggarisbawahi } \\
\text { diksi-diksi puisi }\end{array}$ & $\begin{array}{l}\text { Suka 29 } \\
\text { Tidak suka }\end{array}$ \\
\hline
\end{tabular}

Respon siswa dengan pembelajaran pengkodean puisi memiliki prosentase yang cukup tinggi. Hal ini terasa menyenangkan bagi siswa karena dengan pengkodean diksi saja, mahasiswa sudah dapat menemukan makna puisi itu sendiri. Model pengkodean diksi ini bagi siswa menjadi semacam permainan kata-kata yang nanti akan dijadikan ajang permainan puzzle kemudian dimaknai secara konotatif.

Sedangkan mengapresiasi dengan menggarisbawahi puisi merupakan hal yang menarik bagi siswa. Menariknya, dengan menggarisbawahi puisi, siswa bisa mengambil beberapa elemen kata saja dari puisi tersebut, kemudian, siswa memberikan semacam kode diksi dari satu puisi ke puisi yang lain. Pengkodean ini bertujuan untuk menilai kecenderungan estetika penyair dalam proses menciptakn puisi. Selain itu, dengan pengkodean diksi, siswa dimungkinkan untuk bisa menafsirkan makna puisi tersebut secara mandiri. Dari observasi tersebut bisa ditarik kemungkinan prosentasenya sebagai berikut: 

A. $\frac{20}{12} x 100=16,6 \%$
B. $\frac{29}{3} x 100=96,6 \%$

Dari prosentase diatas dapat disimpulkan bahwasanya poin $\mathrm{B}$ yang lebih tinggi yaitu minat siswa yang menyukai pembelajaran dengan menggarisbawahi diksi-diksi yang akan dibahas sebagai pengapresiasian puisi. Ini mungkin dikarenakan model semacam ini menjadi jalan yang lebih mudah untuk memperlakukan tiap diksi agar menemukan tema, bahkan ide untuk menciptakan sebuah puisi.

\section{Observasi Aktivitas Guru dan Siswa}

Observasi aktivitas guru dan siswa ini selama pengamatan peneliti mengalami aktivitas yang peningkatan yang signifikan. Mungkin hal ini disebaban karena adanya model penawaran pembelajaran baru yang dapat meningkatkan system dan model pembelajaran puisi. Disini, peneliti hanya bisa menyajikan data yang sederhana mengingat keterbatasan peneliti ketika berada dilapangan.

\begin{tabular}{|l|l|}
\hline $\begin{array}{l}\text { Butir Observasi } \\
\text { untuk Guru }\end{array}$ & Skor \\
\hline $\begin{array}{l}\text { Memberikan materi } \\
\text { pelajaran bahasa dan } \\
\text { sastra Indonesia }\end{array}$ & 80 \\
\hline $\begin{array}{l}\text { Memberikan siswa } \\
\text { kesempatan } \\
\text { untuk bertanya }\end{array}$ & 90 \\
\hline $\begin{array}{l}\text { Motivasi guru untuk } \\
\text { semangat belajar }\end{array}$ & 85 \\
\hline $\begin{array}{l}\text { Guru memfasilitasi } \\
\text { siswa dengan belajar } \\
\text { pengkodean diksi }\end{array}$ & 90 \\
\hline Rata-rata & $90 \%$ \\
\hline
\end{tabular}

\begin{tabular}{|l|l|}
\hline $\begin{array}{l}\text { Butir Observasi } \\
\text { untuk Siswa }\end{array}$ & Skor \\
\hline
\end{tabular}

\begin{tabular}{|c|c|}
\hline $\begin{array}{lr}\text { Kemampuan siswa } \\
\text { ketika belajar bahasa } \\
\text { dan sastra Indonesia } \\
\text { dengan } \\
\text { pengkodean diksi }\end{array}$ & 90 \\
\hline \begin{tabular}{lrr} 
Suasana & \multicolumn{2}{r}{ belajar } \\
didalam & kelas & saat \\
proses & pembelajaran \\
bahasa & dan & sastra \\
Indonesia & &
\end{tabular} & 75 \\
\hline $\begin{array}{l}\text { Respon siswa ketika } \\
\text { pembelajaran } \\
\text { berlangsung }\end{array}$ & 90 \\
\hline $\begin{array}{l}\text { Aktivitas dalam kelas } \\
\text { dan semangat siswa } \\
\text { untuk belajar bahasa } \\
\text { dan sastra Indonesia }\end{array}$ & 85 \\
\hline Rata-rata & $88 \%$ \\
\hline
\end{tabular}

Dari data diatas dapat disimpulkan bahwa hasil dari pembelajaran dengan system pengkodean diksi ini mendapat respon positif baik dari guru maupun siswa. Dampak dari hasil ini menjadi motivasi tersendiri bagi guru siswa dan pihak sekolah.

\section{$>$ Pengkodean Diksi}

Pengkodean ini dilakukan dengan cara menggarisbawahi diksi-diksi dari puisi yang sudah disediakan oleh peneliti. Diksidiksi yang digarisbawahi pun tidak ditentukan oleh guru, melainkan siswa sendiri yang menurut mereka diksi mana yang menarik atau sulit untuk dimengerti. Kemudian, dari pengumpulan tersebut, peneliti mencoba mencari asumsi siswa tentang makna diksi yang mereka pilih. Misalnya, jika ada siswa yang kesulitan untuk menemukan makna dari puisi Chairil Anwar yang berjudul $A k u$. Maka siswa dianjurkan untuk memilih beberapa diksi yang menurutnya kurang dimengerti, seperti diksi binatang jalang. Diksi ini memungkinkan banyak interpretasi bagi siswa. Ada yang memaknainya orang yang liar, orang yang putus asa sehingga ia menjadi tidak bisa dikendalikan, bahkan ada yang memaknainya secara linier, yaitu 
binatang secara konkret. Siswa yang seperti inilah yang menjadi objek utama pada peneliti. Karena dalam mengapresiasi puisi dituntut kepekaan simbolik yang kuat. Tentu modal untuk hal tersebut memerlukan perbendaharaan pengetahuan yang luas.

Untuk memenuhi hal tersebut, pengkodean diksi tidak hanya berlaku pada pengapresian saja, tetapi menciptakan sebuah puisi yang punya nilai estetik yang bagus. Siswa dituntut untuk mencari satu kata yang nanti akan dikembangkan menjadi sebuah puisi. Banyak hal yang sebelumnya dilakukan siswa sebelum menemukan kata tersebut, salah satunya dengan membaca beberapa buku puisi atau tulisan-tulisan lain yang fungsinya untuk memancing siswa dalam menemukan kata. Setelah mereka menemukan kata dari apa yang ia baca, barulah peneliti menanyakan kata apa yang mereka temukan. Lalu peneliti menyuruh mereka menuliskan di buku dan mencoba untuk mengembangkannya sesuai selera dan imajinasi mereka. Dari model inilah peneliti mencoba menggunakan pembelajaran puisi dengan model pengkodean. Selain mencoba untuk belajar mengapresiasi, juga berfungsi sebagai penciptaan puisi.

\section{Kesimpulan}

Pada akhirnya, proses pembelajaran puisi dengan model pengkodean diksi cukup mendapat respon positif bagi siswa siswi SMA Kanjeng Sepuh Sidayu Gresik. Respon tersebut beragam, mulai dari minat hingga tidak berminatnya siswa terhadap model tersebut. Siswa yang berminat beranggapan bahwa model pengkodean lebih menarik karena media yang disajikan lebih mudah dicerna. Puisi sendiri bagi mereka sangatlah rumit untuk diapresiasi. Sedangkan bagi siswa yang kurang minat dengan model pembelajaran ini mereka beranggapan bahwa masih tetap saja kurang mengerti dengan pola-pola pengkodean semacam ini. Padahal, peneliti berusaha semaksimal mungkin untuk memberikan terapan yang sederhana dan mudah dicerna yaitu mengapresiasi puisi.

Mungkin, pembelajaran puisi dengan model pengkodean bisa bermanfaat bagi peneliti yang lain walaupun dirasa ada kekurangan dari beberapa hal yang dilakukan oleh peneliti. Salah satunya waktu yang sangat terbatas. Sehingga seolah-olah ada ketergesa-gesaan dalam melakukan penelitian.

\section{Daftar Pustaka}

Aminuddin. 2002. Pengantar Apresiasi Karya Sastra. Bandung: Sinar Baru Algesindo

Arikunto, Suharsimi. 2002. Prosedur Penelitian. Jakarta: PT Rineka Cipta

Arsyad, Azhar. 2007. Media Pembelajaran. Jakarta: PT Grafindo Persada

Depdikbud. 2002. Kamus Besar Bahasa Indonesia. Jakarta: Balai Pustaka

Djojosuroto, Kinayati. 2006. Pengajaran Puisi. Bandung: Nuansa

Jamaluddin. 2003. Problematik Pembelajaran Bahasa dan Sastra. Yogyakarta: Adicita karya Nusa

Keraf, Gorys. 2009. Diksi dan Gaya Bahasa. Jakarta: PT Gramedia Pustaka Utama

Mudlofar. 2004. Bahasa dan Sastra Indonesia. Surabaya: Gema Wacana Alief Muslich, Masnur. 2008. KTSP (Kurikulum Tingkat Satuan Pendidikan) Dasar Pemahaman dan Pengembangan. Jakarta: PT Bumi Aksara

Nurudin. 2007. Dasar-Dasar Penulisan. Malang: Universitas Muhammadiyah Malang

Pradopo, Rachmat Djoko. 2005. Beberapa Teori Sastra, Metode Kritik dan Penerapannya. Yogyakarta: Pustaka Pelajar

Riduwan. 2009. Skala Pengukuran Variabel-variabel Penelitian. Bandung: Alfabeta

Rohani, Ahmad. 1997. Media Instruksional Edukatif. Jakarta: PT Rineka Cipta 
Sadiman, Arief, dkk. 2008. Media Pendidikan. Jakarta: Raja Grafindo Persada Sanjaya, Wina. 2006. Strategi Pembelajaran Berorientasi Standar Proses Pendidikan. Jakarta: Kencana

Sudjana, Nana. 2007. Penelitian dan Penilaian Pendidikan. Bandung: Sinar Baru Algesindo

Suyatno. 2009. Menjelajah Pembelajaran Inovatif. Sidoarjo: Masmedia Buana Pustaka

Tarigan, Henry Guntur. 2008. Menulis Sebagai Suatu Ketrampilan Berbahasa. Bandung: Angkasa

Tjahjono, Tengsoe. 2000. Membidik Bumi Puisi ke Arah Kegiatan Apresiasi. Surabaya: Sanggar Kalimas Surabaya

Wiyanto, Asul. 2005. Kesusastraan Sekolah. Jakarta: Grasindo 